\title{
SIMULATION OF SODIUM AND POTASSIUM DYNAMICS BY THE HYDRUS 2D MODEL IN A HAPLIC PLANOSOL VIA RESIDUE WATER ${ }^{1}$
}

\author{
Carolyne W. L. de Andrade ${ }^{*}$, Suzana M. G. L. Montenegro ${ }^{3}$, Jarbas H. de Miranda ${ }^{4}$, \\ Abelardo A. de A. Montenegro ${ }^{3}$, Fred M. C. V. de Assis ${ }^{3}$
}

${ }^{2 *}$ Corresponding author. Federal Rural University of Pernambuco (UFRPE)/ Recife, PE, Brazil.

E-mail: carolyne.andrade@ufrpe.br

\section{KEYWORDS}

modeling, nutrients, soil physical properties, water reuse.

\begin{abstract}
The application of chemical substances to the soil together with little attention given to the possible environmental impacts, transformed the environment into a recipient of waste. The aim of this study was to simulate the movement of water and solutes (sodium and potassium together) using the STANMOD and HYDRUS-2D models in a typical Haplic Planosol under the application of wastewater via surface irrigation under different flow rates. The experiment was conducted in the laboratory by miscible displacement tests, first using columns with deformed soil under saturation and steady water flow conditions, at a rate of $11.7 \mathrm{~cm}^{3} \mathrm{~min}^{-1}$, to obtain transport parameters of sodium and potassium ions, and in the applied residual water, the values of 475 and $76.6 \mathrm{mg} \mathrm{dm}^{-3}$, respectively. The transport parameters were estimated from the numerical adjustment of effluent distribution curves, using the STANMOD model. In a second step, the HYDRUS-2D model was applied to simulate the volumetric soil moisture distribution profiles, as well as the ion concentrations in the wet bulb. Considering the results obtained, we can see that there was considerable interaction between the solutes and the soil. The value of the delay parameter was higher for the sodium when compared to the potassium, reflecting its greater adsorption and the processes of exchange between the solute and the soil. The results suggested the need for adequate soil management in order to avoid future soil sodification and, in view of the application of HYDRUS-2D, it was verified that the model presented a satisfactory performance in the simulation of the displacement of the ions, after 1, 5 and 10 hours of wastewater application.
\end{abstract}

\section{INTRODUCTION}

In the last decades, there has been a greater concern with issues related to the environment, such as water scarcity and increased production of waste from a wide variety of activities. An alternative to minimize such problems is the reuse of treated wastewater in agriculture (Andrade, 2014). However, improper use can cause severe impacts, such as pollution of groundwater or the accumulation of solutes in the soil. According to Garcia et al. (2012), the use of effluents in agriculture can increase the levels of substances such as nitrogen and chemical oxygen demand (COD), and interfere with soil microfauna.

The potassium ion $(\mathrm{K})$ is a macronutrient that has important functions for the growth of crops. According to
Miranda et al. (2010), potassium can be considered a mobile ion, and therefore can be easily leached along the soil profile. In relation to the sodium ion $(\mathrm{Na})$, the importance of its quantification is linked to studies involving soil salinity, since high concentrations of this element can cause negative effects on crops, such as decreased growth and yield. It may also affect the soil structure, because sodium excess can cause the dispersion of clays, causing the decrease of soil permeability.

According to Arienzo et al. (2012), researches involving the relations of sodium and potassium ions with cation exchange capacity (CEC) of soils with different mineralogy are of great relevance for the proper management of areas in which wastewater is applied, since

\footnotetext{
${ }^{1}$ Work extracted from the First Author Dissertation.

${ }^{3}$ Federal University of Pernambuco (UFPE)/ Recife, PE, Brazil.

${ }^{4}$ Luiz de Queiroz College of Agriculture (ESALQ/USP), Department of Biosystems Engineering / Piracicaba, SP, Brazil. 
irrigation with such waters can result, for example, in an increase of sodium to the soil, leading to problems such as dilation and dispersion of particles and to the commitment of crop growth.

Irrigation is an essential practice for agriculture in arid and semiarid regions. Due to problems of water scarcity around the world, localized irrigation has been highlighted by its greater efficiency in the use of water (Kandelous et al., 2011; Rodríguez-Sinobas et al., 2012). The water movement in drip systems is influenced by soil hydraulic properties, water content, emitter discharge and irrigation frequency (Rodríguez-Sinobas et al., 2012) and the greater or lesser efficiency of water use through these systems will depend on such characteristics.

Several simulation models, such as STANMOD (STudio of ANalytical MODels) and HYDRUS-2D, have been developed over the years to simulate the movement of water and solutes in the soil (Moura et al., 2013). With the advancement of computer systems and the availability of models that simulate water flow and solute transport in soils, an increasing number of researchers have sought to evaluate the processes involved in the water displacement in irrigated soils with this system (Kandelous et al., 2011, Kandelous et al., 2012). According to Phogat et al. (2014), simulation models have been important research tools in studies involving complex and interactive processes of water flow and solutes transport through the soil profile, as well as the effects of management practices on agricultural production and the environment.

Several studies have applied such models to characterize the displacement of solutes in the soil profile, such as the study developed by Vilela et al. (2018) that obtained the potassium transport parameters in soil columns from the miscible displacement of sewage and potassium chloride $(\mathrm{KCl})$ solutions using the STANMOD model. According to the authors, the potassium applied via sewage has a higher contaminant potential than a $\mathrm{KCl}$ solution. Grecco et al. (2016) evaluated the HYDRUS-2D model in predicting the dimensions of wet bulbs generated by subsurface drippers and verified that the model is a viable option for such prediction. Phogat et al. (2014) used the HYDRUS-2D model to simulate the dynamics of water, salinity and nitrate in drip irrigation area in tangerine crop and verified that adequate management in water and fertilizer applications are important for the reduction of contamination on water resources.

Given the above, the objective of the study was to simulate the movement of water and solutes (sodium and potassium together) using STANMOD (to obtain the transport parameters) and HYDRUS-2D (to simulate ion distribution in a wet volume) in a typical Haplic Planosol under the application of wastewater via surface dripping irrigation under different flow rates.

\section{MATERIAL AND METHODS}

\section{Physical and chemical characterization of soil material}

The experiment was carried out at the Water and Soil Laboratory of the Department of Agricultural Engineering of the Federal Rural University of Pernambuco (UFRPE) and at the Laboratory of Soil Physics of the Department of Biosystems Engineering, Luiz de Queiroz College of Agriculture (ESALQ/USP). The soil material, for filling the columns, was collected in a layer of up to $20 \mathrm{~cm}$ depth of a profile of a typical Haplic Planosol (THP). From Tables 1 and 2, the results of the physical analysis and the characterization of soil chemical attributes can be checked, following the recommendation of the Manual of Soil Analysis Methods (EMBRAPA, 2011).

TABLE 1. Physical characterization of the soil used.

\begin{tabular}{|c|c|}
\hline Physical characteristics & THP \\
\hline \multicolumn{2}{|c|}{ Granulometry $\left(\mathrm{g} \mathrm{kg}^{-1}\right)$} \\
\hline Coarse sand & 220 \\
\hline Thin sand & 576 \\
\hline Silt & 72 \\
\hline Clay & 130 \\
\hline Textural class * & Free sand \\
\hline Soil Density $\left(\mathrm{g} \mathrm{cm}^{-3}\right)$ & 1.50 \\
\hline Particle Density $\left(\mathrm{g} \mathrm{cm}^{-3}\right)$ & 2.64 \\
\hline Porosity (\%) & 43.02 \\
\hline Saturated hydraulic conductivity $\left(\mathrm{K}_{0}, \mathrm{~cm} \mathrm{~h}^{-1}\right)$ & 14.73 \\
\hline
\end{tabular}

*Classification according to USDA.

TABLE 2. Chemical soil characteristics at 0-20 cm depth.

\begin{tabular}{ccccccc}
\hline $\mathbf{C a}^{2+}$ & $\mathbf{M g}^{2+}$ & $\mathbf{K}^{+}$ & $\mathbf{N a}^{+}$ & $\mathbf{A l}^{\mathbf{3}^{+}+\mathbf{H}^{+}}$ & $\mathbf{C E C}$ & $\begin{array}{l}\mathbf{O} . \mathbf{M} \\
\mathrm{cmol}_{\mathrm{c}} \mathrm{dm}^{3}\end{array}$ \\
\hline 1.57 & 0.6 & 2.18 & 3.83 & 0.4 & 8.58 & 23.89 \\
\hline
\end{tabular}

$\mathrm{CEC}=$ soil cation exchange capacity; O.M. = Organic matter content in the soil. 
For the determination of the soluble cations present in the soil solution (Table 3), it was extracted from a saturated paste, according to methodology proposed by EMBRAPA (2011).

TABLE 3. Composition from the extract of the soil saturated paste at depth $0-20 \mathrm{~cm}$.

\begin{tabular}{ccccccc}
\hline pH water & $\begin{array}{c}\mathbf{E C} \\
\mathrm{dS} \mathrm{m} \mathrm{m}^{-1}\end{array}$ & $\mathbf{C a}^{2+}$ & $\mathbf{M g}^{2+}$ & $\begin{array}{c}\mathbf{K}^{+} \\
\mathrm{mmol}_{\mathrm{c}} \mathrm{dm}^{3}\end{array}$ & $\mathbf{N a}^{+}$ & $\mathbf{S A R}$ \\
\hline 7.89 & 2.67 & 3.99 & 1.27 & 2.12 & 15.84 & 9.77 \\
\hline
\end{tabular}

$\mathrm{EC}=$ Electrical conductivity, $\mathrm{SAR}=$ Sodium adsorption ratio

Table 4 shows the parameters of the water retention curve in the soil according to the van Genuchten model (1980), eqs. (1) and (2).

TABLE 4. Physical-water parameters of the soil according to the van Genuchten model (1980).

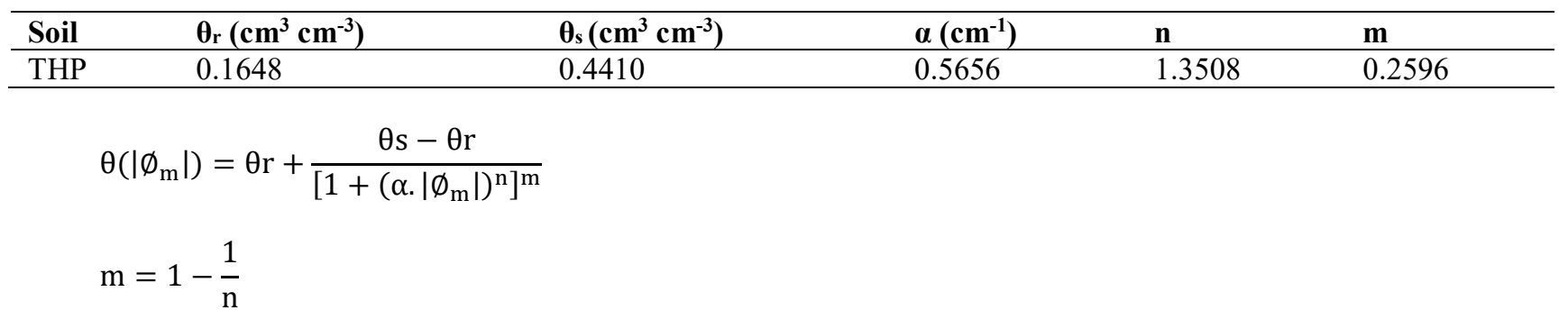

Where:

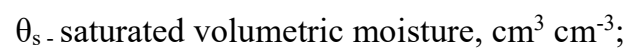

$\theta_{\mathrm{r}}$ - residual volumetric moisture, $\mathrm{cm}^{3} \mathrm{~cm}^{-3}$;

$\alpha$ - parameter of soil water retention function, $\mathrm{cm}^{-1}$;

$\mathrm{n}$ and $\mathrm{m}$ - parameters of soil water retention function, dimensionless, and

$\phi_{\mathrm{m}}$ - soil matric potential, $\mathrm{cm}$.

\section{Characterization of the wastewater}

The wastewater used came from the Mangueira Sewage Treatment Station (ETE - Mangueira), located at $8^{\circ} 05^{\prime} 41^{\prime \prime}$ south latitude and $34^{\circ} 55^{\prime} 31^{\prime \prime}$ west longitude and $1 \mathrm{~m}$ altitude (Silva, 2009), in Recife, PE. The station uses the anaerobic process of sewage treatment, using an upflow anaerobic reactor (UASB), followed by a polishing pond. Table 5 shows the chemical characterization of the wastewater, based on the methodologies described in the EMBRAPA (2011).

TABLE 5. Characterization of wastewater

\begin{tabular}{|c|c|c|c|c|c|}
\hline $\begin{array}{c}\mathrm{ECw} \\
\left(\mathrm{dS} \mathrm{m}^{-1}\right)\end{array}$ & $\begin{array}{c}\mathrm{Ca}^{2+} \\
\left(\mathrm{mg} \mathrm{L}^{-1}\right)\end{array}$ & $\begin{array}{c}\mathrm{Mg}^{2+} \\
\left(\mathrm{mg} \mathrm{L}^{-1}\right)\end{array}$ & $\begin{array}{c}K^{+} \\
\left(m g L^{-1}\right)\end{array}$ & $\begin{array}{c}\mathrm{Na}^{+} \\
\left(\mathrm{mg} \mathrm{L}^{-1}\right)\end{array}$ & $\begin{array}{c}\text { SAR } \\
\left(\mathrm{mg} \mathrm{L}^{-1}\right)\end{array}$ \\
\hline 0.57 & 9.0 & 5.9 & 2.8 & 24.2 & 8.87 \\
\hline
\end{tabular}

$\mathrm{ECW}=$ Electrical conductivity of water, $\mathrm{SAR}=$ Sodium adsorption ratio

\section{Parameters of solutes transport}

The transport parameters were obtained by numerical adjustment of the effluent curves or Breakthrough Curve (BTC), which are: Peclet number (P), dispersion coefficient (D), Peclet number as a function of the Dispersivity $(\lambda-\mathrm{P}(\lambda))$, Peclet number as a function of water velocity in the pores $(\mathrm{P}(v))$ and retarding factor $(\mathrm{R})$.

The Peclet number (equation 3 ) is a dimensionless parameter used in the study of the movement of the solutes through a porous medium and allows to determine which mechanism (convection-dispersion or diffusion) dominates the solutes transport process (Gonçalves et al. 2008), expressing the relation between transport velocity by convection and transport velocity by molecular diffusion. Lower values of the Peclet number indicate that the diffusion transport is larger than the convective transport.
For higher values of Peclet number, the convectiondispersion transport is superior to diffusion (Gonçalves et al., 2008).

$$
\mathrm{P}=\frac{v \cdot \mathrm{L}}{\mathrm{D}}
$$

Where:

$$
\begin{aligned}
& v \text { - water velocity in the pores, } \mathrm{cm} \mathrm{min}^{-1} \text {; } \\
& \text { L - soil column length, } \mathrm{cm} \text {, and } \\
& \text { D - dispersion coefficient, } \mathrm{cm}^{2} \mathrm{~min}^{-1} \text {. }
\end{aligned}
$$

The dispersion coefficient (equation 4) is generally assumed to be a function of the fluid velocity; the velocity value can be obtained by the relation between the flow of water in the soil and the volumetric moisture: 


$$
\mathrm{D}=\lambda \cdot v
$$

Where:

$\lambda$ - dispersivity of the porous medium, $\mathrm{cm}$, and

$v$ - water velocity in the pores, $\mathrm{cm} \mathrm{min}^{-1}$.

According to Valocchi (1984), the retarding factor ( $\mathrm{R}$ - equation 5) represents the difference between the advancement velocity of the solute and the advancement velocity of the wetting front of the solution, thus representing the interaction between the solute and soil solid phase (adsorption or desorption).

$$
\mathrm{R}=1+\frac{\rho \cdot \mathrm{K}_{\mathrm{d}}}{\theta}
$$

in which:

$\mathrm{R}$ - retarding factor, dimensionless;

$\rho$ - soil density, $\mathrm{g} \mathrm{cm}^{-3}$;

$\mathrm{Kd}$ - empirical coefficient of elution (equal to zero when there is no interaction between solute and soil, dimensionless, and

$\theta$ - volumetric water content, $\mathrm{cm}^{3} \mathrm{~cm}^{-3}$.

The STANMOD (STudio of ANalytical MODels) program (Šimůnek et al., 2008), which has the code CFITIM, was used to adjust the sodium and potassium transport parameters. This code analyzes effluents observed in soil columns (BTC) using analytical solutions of convective-dispersive transport equations for equilibrium or non-equilibrium, in one dimension, including analytical solutions for semi-finite columns. The code is easy to implement by the user, efficient and has the precise means to determine various transport parameters by optimizing the BTC column effluent data.

\section{Filling the columns for the elaboration of the BTCs}

Acrylic columns $30 \mathrm{~cm}$ high and $6 \mathrm{~cm}$ in diameter were used, which were filled with the aforementioned soil material in constant, equivalent and homogeneous layers. In the lower part of the columns we placed a synthetic blanket circle on a screen, fixed by a cap, for the support of the material, in order to avoid the loss of soil during the tests; in the upper part of the column was placed a synthetic blanket circle, so as to provide better distribution of the liquid to be percolated on the surface and to guarantee the uniformity of infiltration of the solution in the soil. The application of the wastewater was as follows: first the column was saturated by upflow with deionized water for a period of 24 hours to complete the saturation process. It remained resting for a period of 24 hours (saturated) and only at that moment the process of deionized water application was initiated, maintaining a hydraulic load constant of $1 \mathrm{~cm}$. This procedure was carried out for a period of 24 hours in order to remove the sodium and potassium present in the soil solution and in the exchange complex by a "washing" process. After washing, it was found in each experimental unit whether the flow density was in permanent state condition. Once the permanent flow condition was established, the exchange of the deionized water was initiated by the passage of the wastewater through the upper part of the column. That is, to promote soil saturation in the column and start the tests, the same procedures were followed by Rossi et al. (2007), replacing the PVC columns with acrylic columns and the water distilled by deionized water, as well as the use of a sodium ion and potassium ion meter in the wastewater. The effluent was applied at the top of the column (Figure 1). Four experimental units were used, that is, four soil columns that represented repetitions.

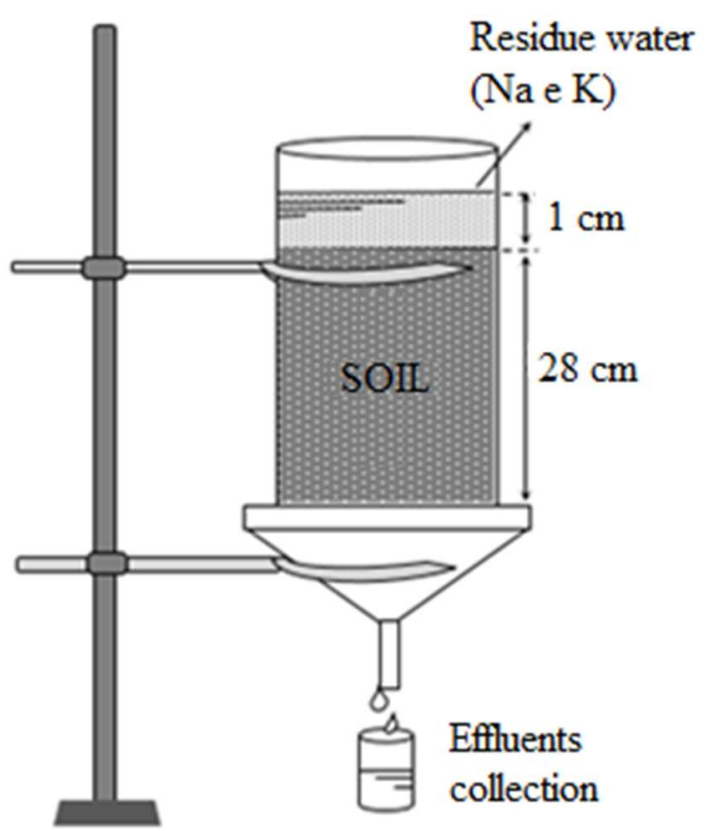

FIGURE 1. Experimental scheme used to elaborate Breakthrough Curves

An effluent with a concentration of $475.37 \mathrm{mg} \mathrm{L}^{-1}$ of sodium and $76.64 \mathrm{mg} \mathrm{L}^{-1}$ of potassium was applied and sequential volumes of effluents of $20 \mathrm{~mL}$, representing fractions of 0.055 volume of pores (VP) were collected. The VPs were calculated according to the soil volume of the columns, $791.68 \mathrm{~cm}^{3}$ and the porosity of the soil material (equation 6):

$$
1 \mathrm{VP}=\alpha \mathrm{V}
$$

Where:

$$
\begin{aligned}
& \mathrm{VP} \text { - volume of pores, } \mathrm{cm}^{3} ; \\
& \alpha \text { - porosity of the soil in question, } \mathrm{cm}^{3} \mathrm{~cm}^{-3} \text {, and } \\
& V \text { - column volume, } \mathrm{cm}^{3} \text {. }
\end{aligned}
$$

To help estimate the duration of the effluent collection process, a flame emission photometer was used for sodium and potassium; the BTC test was interrupted only when the relative concentration $(\mathrm{C} / \mathrm{Co})$ was 1.0 , that is the initial concentrations at the inlet were equal to the concentrations at the outlet of the column.

\section{Input data on the HYDRUS-2D model}

The temporal detailing of the model was defined, being the same for all the numerical simulations, with an initial time interval of $0.0024 \mathrm{~h}$, with a minimum of 0.000024 $\mathrm{h}$ and a maximum of $120 \mathrm{~h}$. The initial time was considered 
as "zero", and the final time after $10 \mathrm{~h}$ of application of the wastewater. The different inlet flows of the wastewater were determined by the saturated disk area provided by the dripper $\left(733.28 \mathrm{~cm}^{2}\right)$. In order to obtain the flow densities, the flow rates of the dripper $\left(2,4\right.$ and $\left.6 \mathrm{~L} \mathrm{~h}^{-1}\right)$ were divided by the area, which allowed to obtain the following values for the flow density: $2.73 ; 5.45 ; 8.18 \mathrm{~cm} \mathrm{~h}^{-1}$. These treatments were used for all simulations. The model of the hydraulic properties adopted was of van Genucthen (1980), without considering the hysteresis phenomenon.

With the HYDRUS-2D model, it was possible to model the vertical section of the wet bulb in which it was desired to perform the simulations of the residual water dynamics in the soil; in this way, a section of height and width of $100 \mathrm{~cm}$ was defined, with the dripper installed on the surface of the area, on the left. For spatial detailing, a non - structured finite element mesh size of $5 \mathrm{~cm}$ was used. The time of 1,5 and $10 \mathrm{~h}$ were defined to observe the water content and the concentrations of the studied solutes at each depth of the soil profile.

The upper contour condition was of constant flow where the dripper was located, and the inferior contour as free drainage, and the initial conditions of soil water content being determined by the residual volumetric moisture of the soil under study. The equilibrium model was adopted for solute transport in all simulations, considering a pulse duration always higher than the total application time, which represents continuous application of the same concentration throughout the test. The initial conditions of the solutes in the soil were based on the concentrations found in the chemical analysis, that is $0.01584 \mathrm{mmol} \mathrm{cm}^{-3}$ for sodium and $0.00212 \mathrm{mmol} \mathrm{cm} \mathrm{cm}^{-3}$ for potassium.

\section{RESULTS AND DISCUSSION}

\section{Parameters of sodium and potassium transport}

The effluent distribution curves (for sodium and potassium ions, numerically adjusted by the STANMOD model), based on the data obtained in the laboratory, can be checked by Figure 2. In all the effluent curves of the studied soil were reached in the leachate, at $90 \%$ of the initial concentration applied.

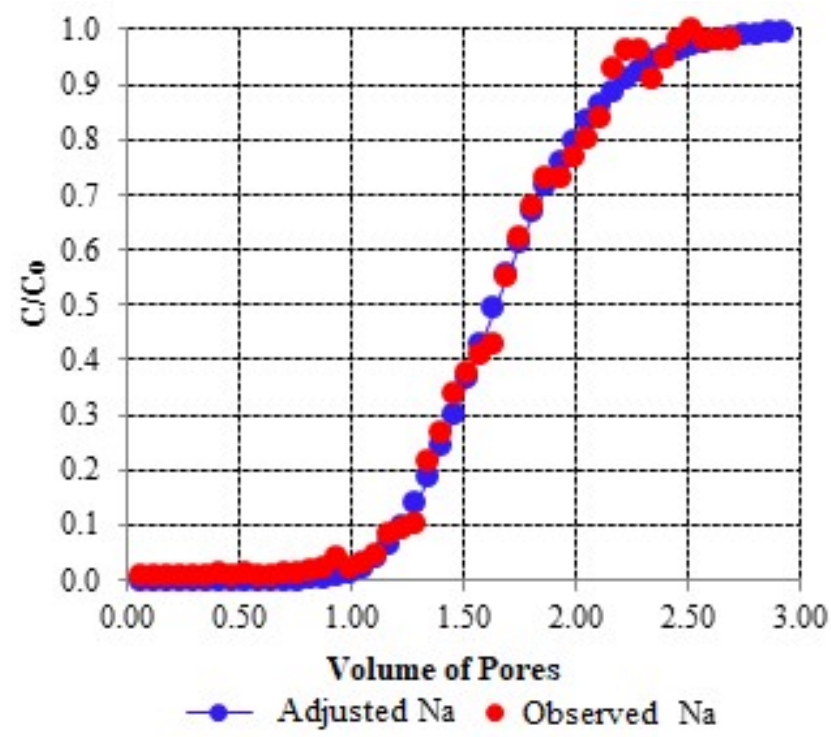

FIGURE 2. Distribution of wastewater effluent curves using the STANMOD model, sodium ion (A) and potassium ion (B)

We can notice from Figure 2 that the sodium ion required a greater number of pore volumes (VP) to reach $90 \%$ of the relative concentration, being this value approximately $2.2 \mathrm{VP}$, when compared to the potassium ion, which only needed 2.0 VP. This fact indicates that there was a greater interaction of sodium with the soil matrix. Silva et al. (2012), studying the distribution of solutes in columns of eutrophic Red Nitosol with vinasse, found that potassium required a minimum amount of $2.6 \mathrm{VP}$ so that the initial concentration was reached, while sodium needed 1.8 VP, not exceeding $2 \mathrm{VP}$.

While the effluent distribution curves characterize the displacement of these solutes in the soil, the transport parameters, obtained through their adjustments, quantify this movement (Table 6). The velocity of the solution entering the pores $(v)$ was the same for both solutes, that is, $0.63 \mathrm{~cm} \mathrm{~h}^{-1}$, because the solutes were in the same solution applied in the effluent curves.

TABLE 6. Parameters of sodium and potassium transport: Peclet number $(\mathrm{P})$, dispersivity $(\lambda)$, dispersive-diffusive coefficient (D) and retarding factor (R), in a typical Haplic Planosol (THP).

\begin{tabular}{ccccc}
\hline \multirow{2}{*}{ Solutes } & $\mathbf{P}$ & \multicolumn{2}{c}{ Transport Parameters } & $\mathbf{D}$ \\
& & $\boldsymbol{\lambda}$ & $\mathbf{D}$ & $\mathbf{R}$ \\
$\mathbf{c m}^{\mathbf{2}} \mathbf{~ m i n}^{-\mathbf{1}}$ & 0.46 & 1.68 \\
Sodium $(\mathrm{Na})$ & 38.50 & 0.73 & 13.61 & 1.12 \\
Potassium $(\mathrm{K})$ & 3.03 & 21.51 & & \\
\hline
\end{tabular}


The values obtained from the Peclet $(\mathrm{P})$ number for sodium were higher than for potassium. Silva et al. (2012) also found higher values of ' $\mathrm{P}$ ' for sodium in relation to the potassium ion. The higher value of ' $\mathrm{P}$ ' for sodium confirms the higher velocity of advection in the first case, due to the lower dispersivity $(\lambda)$ of the solute and the higher retarding factor, responsible for the higher cation interaction with the soil matrix. The higher retarding factor evidences the greater solute-soil interaction (Vilela et al., 2018). In order to evaluate the performance of the HYDRUS-1D model in the simulation of the transport of water and potassium in tropical soils, Pinho \& Miranda (2014) reported a higher Peclet for the Red Yellow Latosol compared to the Red Nitosol, confirming the higher velocity of advection for the first soil.

Both sodium and potassium are monovalent ions $\left(\mathrm{Na}^{+}\right.$and $\left.\mathrm{K}^{+}\right)$, but have different hydrated ray values. Potassium is the lowest hydrated ray, while sodium has the largest hydrated ray. Minor cations tend to displace larger cations. This means that potassium has a greater ability to displace sodium (Ritter et al., 1999).

However, in the present study, the relative abundance of sodium in the soil solution (Table 3 ) is higher than that of potassium, thus occurring greater presence of sodium in the clay sites, replacing the potassium, which leached into the soil profile. The research conducted by Vilela et al. (2018) showed that the potassium applied via sewage had lower soil adsorption when compared to a solution of potassium chloride $(\mathrm{KCl})$, and therefore, the sewage presented a higher potential contaminant in relation to a solution of $\mathrm{KCl}$. Thus, the higher adsorption of the sodium ion to the soil verified in this study represents a lower contaminant potential of this solute in relation to the potassium ion. However, in the application of the effluent in agricultural areas, the sodium ion, although important in terms of lower groundwater contamination, should be monitored, since its presence in the soil matrix can influence the development of plant species and compromise the agricultural production.

The processes that govern the displacement of the potassium ion in the soil are related to its ability to exchange with other cations (CEC) in the soil. When CEC is slightly larger than the amount of potassium in the soil, the adsorption mechanism is controlled mainly by changes in the potassium concentration in the soil solution. As the concentration of potassium in the soil solution increases, its buffering capacity decreases, and its velocity of movement increases (Miranda et al., 2010). It can be observed in Tables 1 and 2 that, in the soil used, the percentage of clay and the CEC have low values, resulting in a smaller amount of negative charges present in the soil matrix, a characteristic that is common in sandy soils; for these reasons, the degree of leaching of the ion has become greater than the retention by the soil.

\section{Simulations of water dynamics by the HYDRUS-2D model}

The water dynamics in a typical Haplic Planosol (THP) was performed by applying the HYDRUS-2D model, by varying the time and the flows used in the dripper (Figure 3). We observed that the formation of the wet bulb shows a greater vertical displacement than the horizontal one, due to the predominance of macrospores, responsible directly for the conduction of the water in the soil during the processes of infiltration, being this a characteristic present in sandy soils. Pinho \& Miranda (2014) verified that soils with different textures influenced the movement of water and potassium in the soil. According to the authors, in the Red-Yellow Latosol (sandy-loam texture), water and potassium reached greater depths along the column, compared to Red Nitosol (clay texture). That is, the model was sensitive to this soil characteristic. We also verified that the model was able to simulate that with the treatment of 6 $\mathrm{L} \mathrm{h}^{-1}$, the wetting front in the soil profile reached the last layer $(90-100 \mathrm{~cm})$, which was already expected by the higher volume of water applied by the dripper (Figure 3). Differently from the results found in this study (greater vertical displacements of water and ions), Grecco et al. (2016) found greater horizontal displacements in all ten applications of nutrients to the soil, considering the treatments of $1.0 \mathrm{~L} \mathrm{~h}^{-1}$ and $1.6 \mathrm{~L} \mathrm{~h}^{-1}$.

\section{Simulations of the sodium and potassium dynamics by the HYDRUS-2D model}

From the numerical simulations obtained by the HYDRUS-2D model, it was possible to observe the dynamics of sodium and potassium ions (Figures 4 and 5), as a function of the time and the flow rates used in the dripper. It can be noticed that the application of the wastewater to the soil caused an increase in the sodium concentration in the profile layers, with the concentration applied $\left(0.0207 \mathrm{mmol} \mathrm{cm}^{-3}\right)$ higher than that found in the soil $\left(0.01584 \mathrm{mmol}\right.$ in $\left.\mathrm{cm}^{-3}\right)$. We can see that the sodium was displaced in practically the entire soil profile, up to the depth of $65 \mathrm{~cm}$, in the time of $10 \mathrm{~h}$, with a flow rate of $6 \mathrm{~L}$ $\mathrm{h}^{-1}$ (Figure 4).

In the potassium movement in the soil from the application of the wastewater (Figure 5), a 'wash' was observed, that is, a lower concentration $\left(0.0020 \mathrm{mmol} \mathrm{cm}^{-3}\right)$ was applied in relation to the one present in the soil $(0.00212$ mmol cm $\mathrm{cm}^{-3}$ ). However, unlike sodium, potassium reached a vertical displacement greater than $90 \mathrm{~cm}$, due to a greater dispersivity in the soil and less interaction with the soil matrix found in the transport parameters, which was caused by the substitution with sodium in the clay sites from soil. 


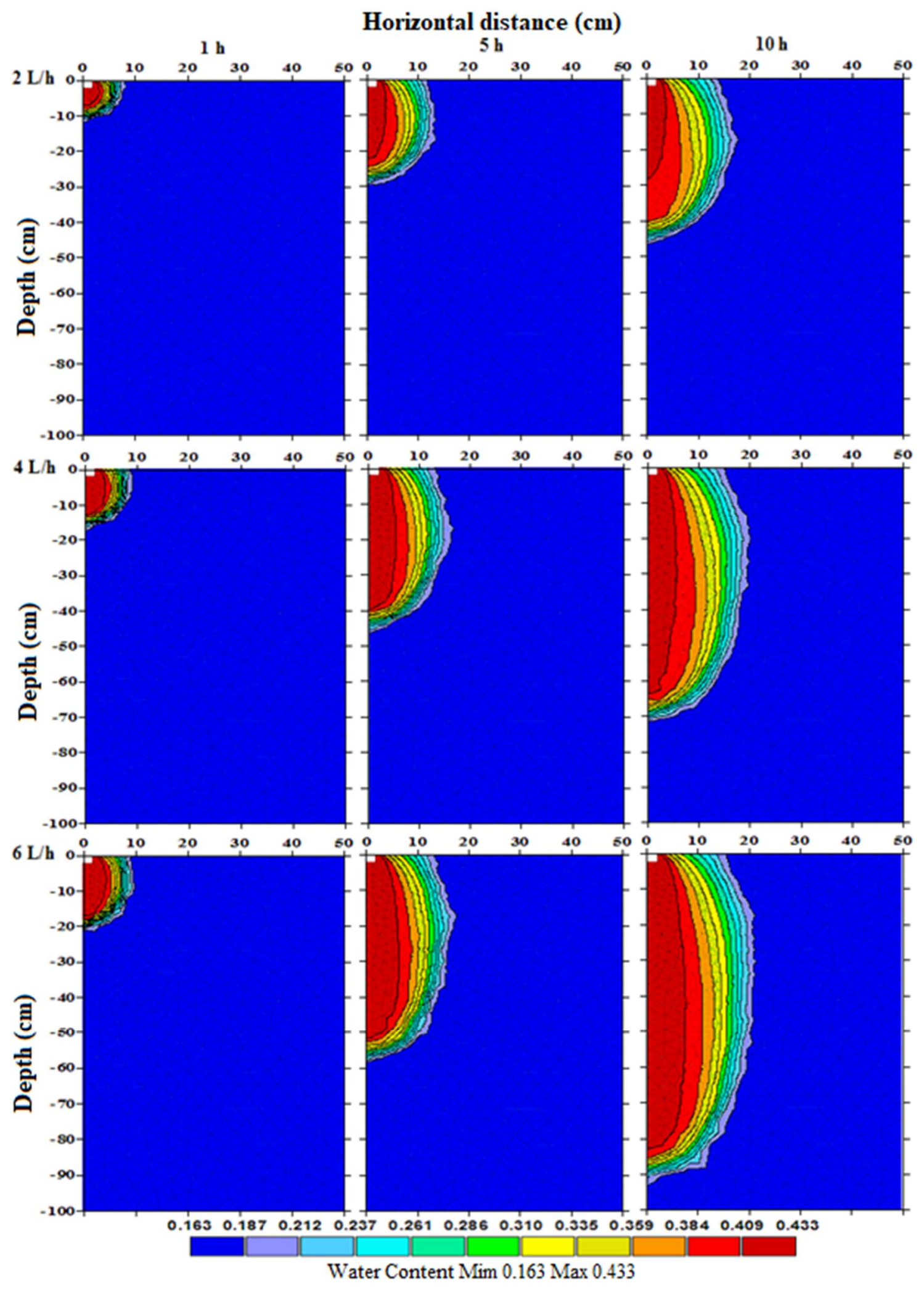

FIGURE 3. Simulated profiles of soil volumetric moisture for different application times and dripper flows 


\section{Horizontal distance (cm) 5 b}
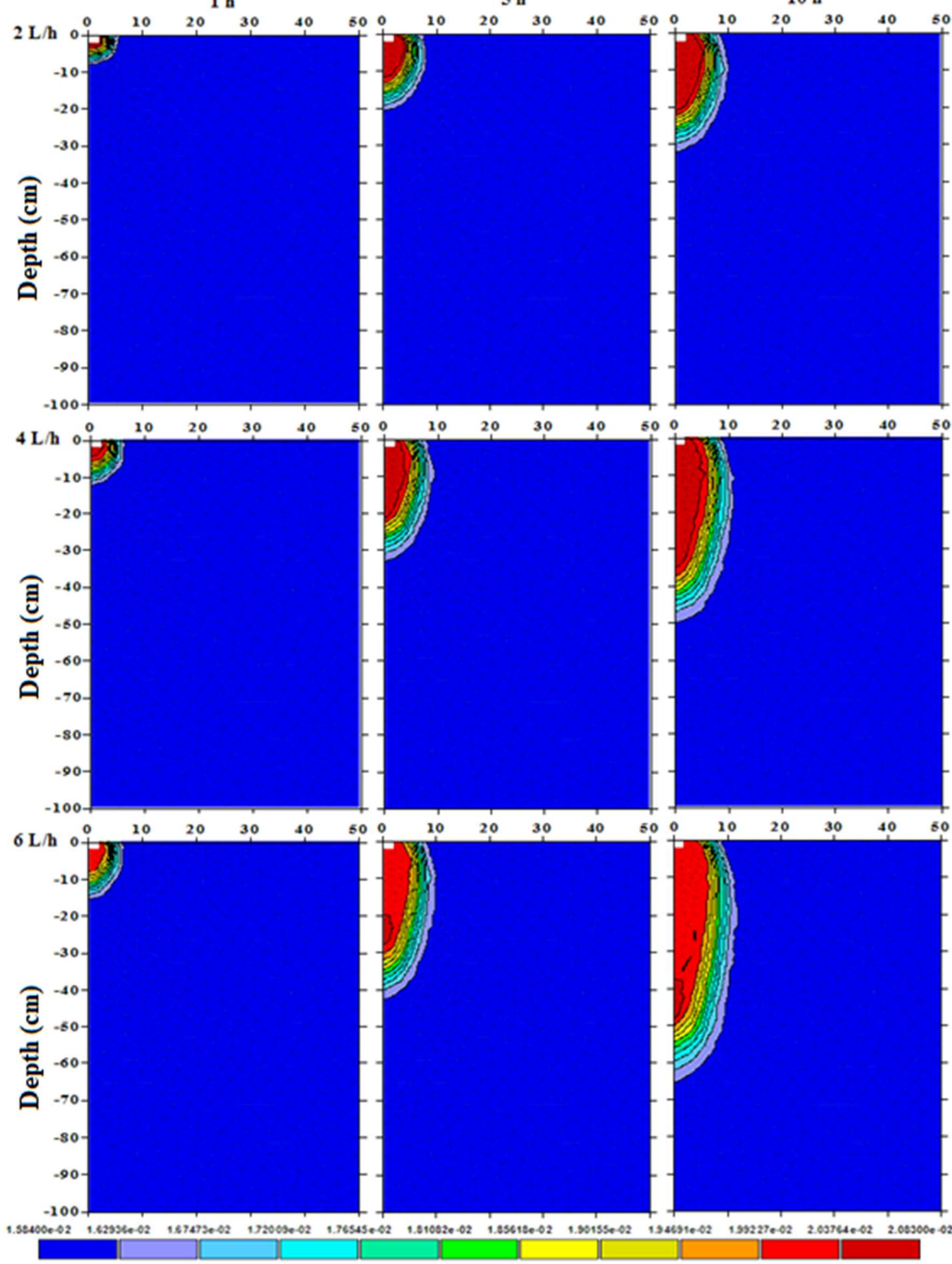

Concentration Mim $0.016 \mathrm{Max} 0.021$

FIGURE 4. Simulated profiles of sodium concentration in the soil solution for different application times and dripper flows 


\section{Horizontal distance $(\mathrm{cm})$}

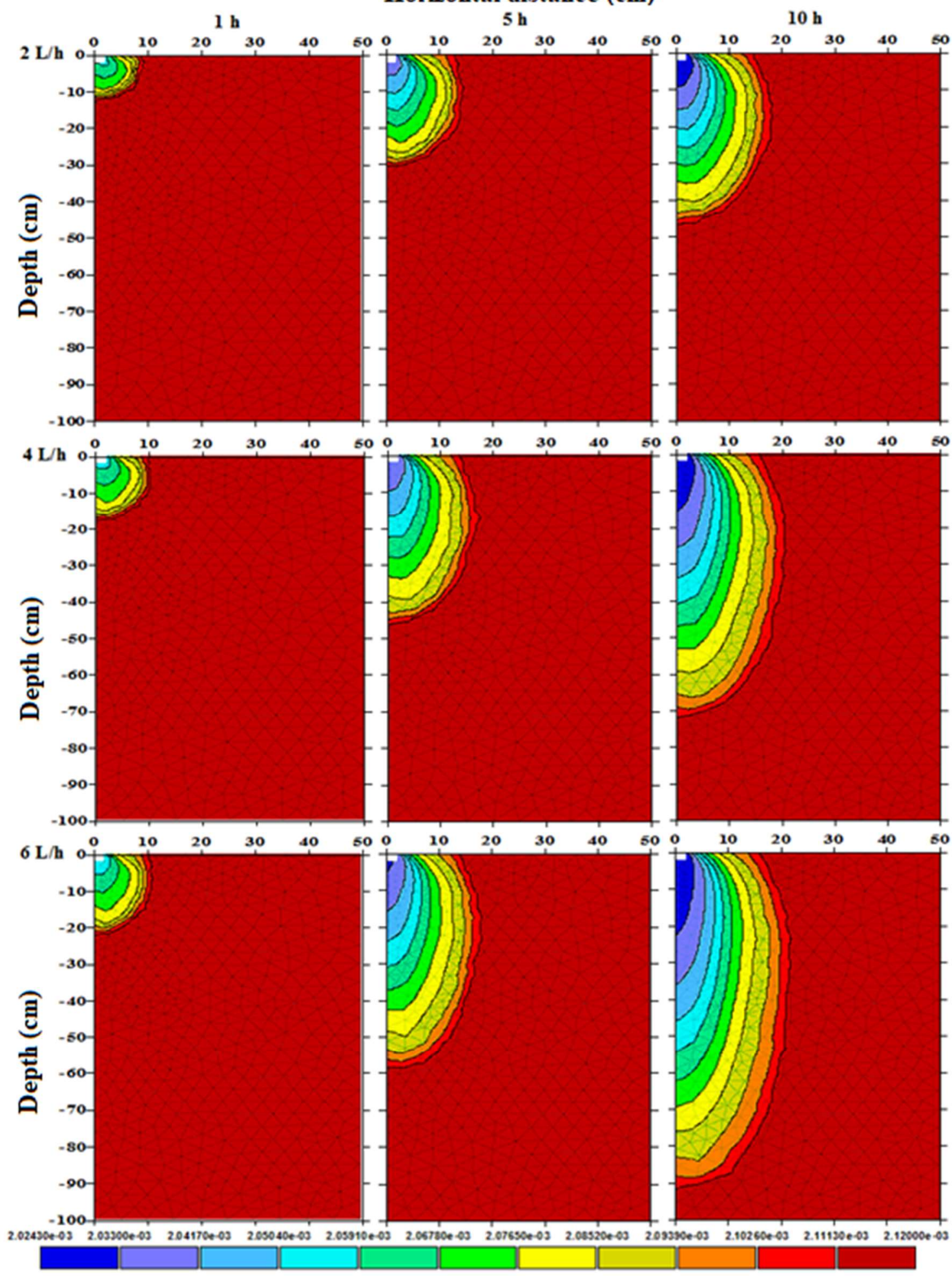

Concentration Mim 2.02430e-3 Max 2.1200e-3

FIGURE 5. Simulated profiles of potassium concentration in the soil solution for different application times and dripper flows

Although sodium was a monovalent cation, the soil was able to retain this solute with greater intensity, as the mass flow advanced (Andrade, 2014). Santos et al. (2010), studying the mobility of sodium, potassium, calcium and magnesium ions under the application of domestic and swine waste water, observed that magnesium and sodium ions were retained in the soil with higher intensity in relation to calcium and potassium ions. However, Silva et al. (2012), observed an opposite effect, where the sodium ion was retained in the soil with less intensity than the potassium ion. Brito et al. (2007), when evaluating the sodium and potassium retention power of Nitossol, Argissol and Espodossol, under the application of vinasse doses, verified that despite the increase in $\mathrm{Na}$ concentration, all the soils had a high retention power of this cation. This fact was also observed in the present study, where sodium, which presents in higher concentration in the applied wastewater, was retained with greater intensity than potassium. 
This result can be explained by the high sodium adsorption ratio (SAR) of domestic wastewater used in the present work. SAR represents one of the main parameters to evaluate the degree of sodification of a soil. Most domestic wastewater is characterized by high sodium concentration and medium or high salinity. Therefore, irrigation with domestic effluent usually results in an increase of soil sodification; thus, a greater concern with agricultural management is needed when using wastewater.

\section{CONCLUSIONS}

In view of the results obtained by the simulations, we concluded that: a) the sodium ion presented higher adsorption to the soil in relation to the potassium ion, and the exchange processes are greater between this solute and the soil; b) the results suggest a need for a proper management of this type of soil, by applying wastewater of this quality, to avoid future soil sodification and c) the HYDRUS-2D model was able, once the properties of solutes transport and physical-water characteristics of the soil were known, to simulate the distribution profiles, in a solution of soil with the presence of sodium and potassium in a typical Haplic Planosol under the application of wastewater via dripping and thus verify the factors which influence the displacement of these ions.

\section{ACKNOWLEDGMENTS}

This work was supported in part by the Support Foundation of Science and Technology of Pernambuco (FACEPE) for granting scholarships to the first author, National Council for Scientific and Technological Development (CNPq) by the PQ grants. This study was also financed in part by the Coordination for the Improvement of Higher Education Personnel (CAPES) - Finance Code 001. The authors would like to thank the team of the Laboratory of Water and Soil of the Department of Agricultural Engineering of the Federal Rural University of Pernambuco (UFRPE), and the Laboratory of Soil Physics of the Department of Biosystems Engineering (Luiz de Queiroz College of Agriculture (ESALQ/USP)) and the PROCAD Program (CAPES) developed between UFRPE, ESALQ / USP and the Federal University of Viçosa. We are also grateful for all important comments from the anonymous reviewers, which contributed to a significant upgrade of the manuscript.

\section{REFERENCES}

Andrade CWL (2014) Caracterização hidrodispersiva de um Planossolo Háplico do semiárido sob reúso agrícola. 124f. Dissertação Mestrado, Recife, Universidade Federal Rural de Pernambuco.

Arienzo M, Christen EW, Jayawardane NS, Quayle WC (2012) The relative effects of sodium and potassium on soil hydraulic conductivity and implications for winery wastewater management. Geoderma 173-174:303-310. DOI: http://dx.doi.org/10.1016/j.geoderma.2011.12.012

Brito FL, Rolim MM, Pedrosa ER (2007) Concentração de cátions presentes no lixiviado de solos tratados com vinhaça. Engenharia Agrícola 27(3):773-781. Available in: http://scielo.br/pdf/eagri/v27n3/a21v27n3.pdf. DOI: http://dx.doi.org/10.1590/S0100-69162007000400021
EMBRAPA - Empresa Brasileira de Pesquisa Agropecuária (2011) Manual de métodos de análises de solo. Embrapa, 230 p.

Garcia WV, Alcântara MAK, Camargo AO, Izário Filho HJ, Andreote FD (2012) Deslocamento miscível de um efluente de indústria de explosivo em colunas de solo. Bragantia 71(1):98-105. Available in: http://scielo.br/pdf/brag/v71n1/15.pdf. DOI: http://dx.doi.org/10.1590/S0006-87052012000100015

Gonçalves ADMA, Miranda JH, Rossi P, Sabadin JFG, Kamagawa MY (2008) Temperature effect in potassium and nitrate ions in soil transport. Engenharia Agrícola 28(3):438-447. Available in:

http://scielo.br/pdf/eagri/v28n3/a05v28n3.pdf. DOI: http://dx.doi.org/10.1590/S0100-69162008000300005

Grecco KL, Bizari DR, Souza CF (2016) Avaliação do modelo HYDRUS-2D na distribuição do soluto no gotejamento subsuperficial. Revista Irriga (1):113-125. Ed. especial. DOI:

http://dx.doi.org/10.15809/irriga.2016v1n01p113-125

Kandelous MM, Kamai T, Vrugt JA, Šimůnek J, Hanson B, Hopmans JW (2012) Evaluation of subsurface drip irrigation design and management parameters for alfalfa. Agricultural Water Management 109:81-93. DOI: http://dx.doi.org/10.1016/j.agwat.2012.02.009

Kandelous MM, Šimůnek J, van Genuchten MT, Malek K (2011) Soil water content distributions between two emitters of a subsurface drip irrigation system. Soil Science Society of America Journal 75(2):488-497. DOI: http://dx.doi.org/10.2136/sssaj2010.0181

Miranda JH, Bérgamo LR, Reis JBRS, Cruciani DE, Duarte SN (2010) Distribuição da concentração de potássio no solo em lisímetros cultivados com amendoim. Engenharia Agrícola 30(2):253-263. Available in: http://scielo.br/pdf/eagri/v30n2/v30n2a07.pdf. DOI: http://dx.doi.org/10.1590/S0100-69162010000200007

Moura AESS, Carvalho JF, Montenegro SMGL, Carmo AI, Magalhães AG, Sousa CCM, Antonino ACD, Araujo JAC, Melo RO (2013) Determinação de parâmetros hidrodispersivos em solos da zona da mata de Pernambuco. Revista Brasileira de Recursos Hídricos 18(3):109-115. DOI:

http://dx.doi.org/10.21168/rbrh.v18n3.p109-115

Phogat V, Skewes MA, Cox JW, Sanderson G, Alam J, Šimůnek J (2014) Seasonal simulation of water, salinity and nitrate dynamics under drip irrigated mandarin (Citrus reticulata) and assessing management options for drainage and nitrate leaching. Journal of Hydrology 513(26):504516. DOI: http://dx.doi.org/10.1016/j.jhydrol.2014.04.008

Pinho REC, Miranda JH (2014) Avaliação do modelo HYDRUS-1D na simulação do transporte de água e potássio em colunas preenchidas com solos tropicais. Engenharia Agrícola 34(5):899-911. Available in: http://scielo.br/pdf/eagri/v34n5/09.pdf. DOI: http://dx.doi.org/10.1590/S0100-69162014000500009 
Ritter E, Ehrlich M, Barbosa MC (1999) Difusão e sorção de soluções múltiplas e monossoluções em solos argilosos salinos e não salinos. Rio de Janeiro, Universidade Federal do Rio de Janeiro, 8 p.

Rodríguez-Sinobas L, Gil M, Sánchez R, Benitez J (2012) Evaluation of Drip and Subsurface Drip Irrigation in a Uniform Loamy Soil. Soil Science 177(2):1-6. DOI: http://dx.doi.org/10.1097/SS.0b013e3182411317

Rossi P, Miranda JH, Duarte SN (2007) Curvas de eluição de efluentes do íon nitrato em amostras de solo deformadas e indeformadas. Engenharia Agrícola 27(3):675-682. Available in:

http://scielo.br/pdf/eagri/v27n3/a10v27n3.pdf. DOI: http://dx.doi.org/10.1590/S0100-69162007000400010

Santos JS, Lima VLA, Borges Júnior JCF, Silva LVBD, Azevedo CAV (2010) Mobilidade de solutos em colunas de solo com água residuária doméstica e de suinocultura. Revista Brasileira de Engenharia Agrícola e Ambiental 14(11):1226-1233. Available in:

http://scielo.br/pdf/rbeaa/v14n11/v14n11a13.pdf. DOI: http://dx.doi.org/10.1590/S1415-43662010001100013

Silva KKB (2009) Efeitos da irrigação com esgoto tratado sobre o sistema solo-planta (milho) e indução da supressividade a doenças causadas por nematóides. Tese Doutorado, Universidade Federal de Pernambuco, Recife.
Silva NF, Lelis Neto JA, Teixeira MB, Cunha FN, Miranda JH, Coelho RD (2012) Distribuição de solutos em colunas de solo com vinhaça. Revista Irriga 1(1):340-350. Available in:

http://revistas.fca.unesp.br/index.php/irriga/article/viewFil e/457/254. DOI:

http://dx.doi.org/10.15809/irriga.2012v1n01p340

Šimůnek J, van Genuchten MTH, Sejna M (2008) Development and applications of the Hydrus and STANMOD software packages and related codes. Vadose Zone Journal 7(2):587-600. Available in: https://pcprogress.com/Documents/Jirka/Simunek_et_al_VZJ_2008. pdf. DOI: http://dx.doi.org/10.2136/vzj2007.0077

Valocchi AJ (1984) Describing the transport of ionexchanging contaminants using an effective $\mathrm{Kd}$ approach. Water Resources Research 20:499-503. DOI: http://dx.doi.org/10.1029/WR020i004p00499

van Genuchten MTH (1980) A closed-form equation for predicting hydraulic conductivity of unsaturated soils. Soil Science Society of America Journal 44(5):892-898. DOI: http://dx.doi.org/10.2136/sssaj1980.036159950044000500 $02 \mathrm{x}$

Vilela NMS, Thebaldi MS, Leal BP, Silva AV, Martins IP (2018) Parâmetros de transporte do potássio presente em esgotos sanitários dispostos em colunas de solo. Revista Engenharia Agrícola 38(1):135-141. 